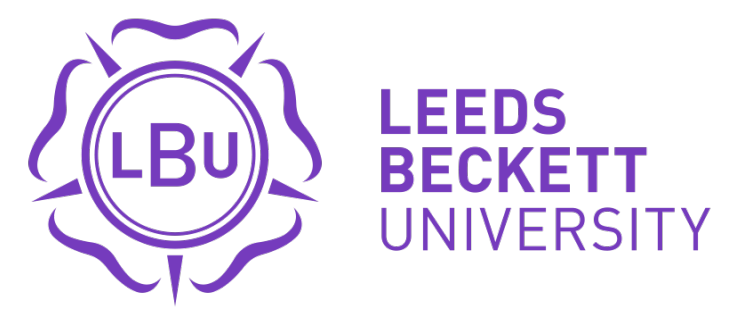

Citation:

Spracklen, K (2014) Moral panics or the politics of pleasure? Alcohol and policy directions in tourism, leisure and events. Journal of Policy Research in Tourism, Leisure and Events, 6 (2). 93 - 94 . ISSN 1940-7963 DOI: https://doi.org/10.1080/19407963.2014.925259

Link to Leeds Beckett Repository record:

https://eprints.leedsbeckett.ac.uk/id/eprint/169/

Document Version:

Article (Accepted Version)

The aim of the Leeds Beckett Repository is to provide open access to our research, as required by funder policies and permitted by publishers and copyright law.

The Leeds Beckett repository holds a wide range of publications, each of which has been checked for copyright and the relevant embargo period has been applied by the Research Services team.

We operate on a standard take-down policy. If you are the author or publisher of an output and you would like it removed from the repository, please contact us and we will investigate on a case-by-case basis.

Each thesis in the repository has been cleared where necessary by the author for third party copyright. If you would like a thesis to be removed from the repository or believe there is an issue with copyright, please contact us on openaccess@leedsbeckett.ac.uk and we will investigate on a case-by-case basis. 


\section{Introduction to the Special Issue: Moral Panics or the Politics of Pleasure? Alcohol and Policy Directions in Tourism, Leisure and Events}

\section{Karl Spracklen, Leeds Metropolitan University, UK}

K.Spracklen@leedsmet.ac.uk

Alcohol has a notorious relationship with human lifestyles - banned in some cultures and religions, central to other cultures and religions. As an accident of organic chemistry (alcohol is the compound ethanol, a product of fermentation processes), alcohol was found to create intoxicating effects on drinkers at least as far back as the Neolithic. Despite historical campaigns of abstinence and temperance, and legal prohibitions such as that which banned the sale of alcoholic drinks in the United States of America, alcohol remains an accepted, everyday part of many cultures and nation-states. Modern Islamic nation-states have attempted to ban or control the use of alcoholic drinks, in accordance with Islamic jurisprudence and dietary laws, but the effectiveness of such legislation and the moral campaigns associated with it varies widely. The consumption of alcohol in tourism, leisure and events spaces and activities is taken for granted in many regions of the world. In certain spaces in the same regions, or in other regions, the consumption of alcohol is banned, limited by policies of control and exclusion, or problematized as a something to be discouraged through changing policy interventions.

This special issue emerged out of the work of the recently formed Alcohol Study Group of the British Sociological Association. I am grateful for the discussions I have had with many inspirational colleagues in that group, especially Patsy Staddon, Tom ThurnellRead and Amanda Rohloff. The founders of the Study Group were concerned that sociological research and critical analysis of alcohol use was constrained by the paradigms of 
medical sociology. I joined the Study Group as a leisure studies researcher and theorist, and brought to the discussions an awareness of the symbiosis between tourism, leisure, events and alcohol. The Alcohol Study Group went from having its own panel at the BSA Medical Sociology conference, to two one-day events culminating in a full multi-day conference in Cardiff, UK, in 2013. Members of the Group have spoken on BBC Radio 4 here in Great Britain, and have continued to raise the profile of alcohol as a serious focus of critical, sociological and policy analysis. As a co-convenor of the Group, I was tasked to try to get a special issue loosely around the critical sociology of alcohol. The multi-disciplinary and inter-disciplinary nature of this journal made Policy Research in Tourism, Leisure and Events an obvious partner, as there is clear synergy between critical policy analysis of tourism, leisure, events, sports and critical policy analysis of alcohol. The workshops and conferences put on by the Group have brought the problem of alcohol into focus, and keynotes such as Chas Critcher have drawn on research and theories that are situated in leisure.

In the research and policy analysis presented at these Group events, it has become clear that a more critical understanding of the relationship between alcohol, tourism, events and leisure is emerging. Alcohol consumption and leisure lives have become a strange paradox in national and global policy arena: sports governing bodies refuse sponsorship from alcohol companies while sports clubs encourage social drinking; Gulf countries ban alcohol except where they sell it to tourists; Government ministers in Europe and elsewhere criticise binge-drinking and stir up moral panics about their citizens’ poor health and behaviour; while tourist industries in alcohol-producing regions rely on selling alcoholic drinks as authentic reminders of trips for tourists returning home. Tensions which emerge between companies, organisations, governments, groups and individuals provide a rich space for academic enquiry into the significance of alcohol in contemporary leisure policy. The drinking of alcohol, then, the cultures, industries and practices associated with its consumption, and its 
relationship to tourism, leisure and events policy-making has become a focus of critical research in social policy.

The six papers presented in this special issue show the diversity of work on alcohol and tourism, leisure and events. There is a key tension between the analysis of alcohol use as the politics of pleasure, and the policy-driven moral panic. There is recognition of the power of the alcohol industry, the tension between capitalism and morality, the tension between maintaining good order and allowing people the chimera of choice. There is awareness of the importance of alcohol to tourism, tourism policy-making and mega-events. In the first paper, Kevin A. Yelvington, Laurel D. Dillon-Sumner and Jason L. Simms draw on rich anthropological fieldwork in wine-making areas of California to explore the ways in which State policy-makers worked with 'wine capitalists' to increase the amount of wine tourism. Yelvington, Dillon-Sumner and Simms show the Community Plan was accepted, but only after negotiation with, and resistance from, local residents and others. In the second paper, Brian E. Menaker and Beth H. Chaney use a case study of US College Football to explore the relationship between the bad behaviour of spectators, alcohol use and policies around the sale of alcohol in the venues. Menaker and Chaney show that alcohol bans may not limit the amount of alcohol-related misconduct. In the third paper, I use the white paper on independence published in 2013 by the Scottish Government to explore the relationship between the whisky industry, tourism policies, health policies and claims for the economic benefits of Scottish independence. I argue that the white paper and other public policy statements and plans show that the health policies and tourism/economic policies are diametrically opposed. In the fourth paper, Sarah Gee undertakes a discourse analysis of narratives surrounding the use of alcohol by spectators at New Zealand's Wellington Rugby Sevens. Gee shows that the media are instrumental in creating what she identifies as a neoteric moral panic, amplifying social unease into full-blown scare-mongering and myth- 
making. In the fifth paper, moral panics appear again in the fieldwork of Will Haydock in the night-time economy spaces of Bournemouth, UK. Haydock shows how policies to promote the city’s night-time economy run alongside reactions against drinking from local residents and others. Finally, Susan Dun reviews the status of alcohol-use in planning and policymaking around Qatar's hosting of the men’s soccer World Cup. Dun shows that there are unresolved tensions between local policies and policy-makers, the interests of FIFA and its sponsors, and potential World Cup tourists. 